PEDULI: Jurnal Ilmiah Pengabdian Pada Masyarakat, 2021, Vol.5, No.2 ISSN: 25974653. EISSN:25974688

http://peduli.wisnuwardhana.ac.id/index.php/peduli/index

\title{
PENDAMPINGAN PENYUSUNAN SOAL AKM NUMERASI UNTUK GURU MATEMATIKA SMP DI KOTA PROBOLINGGO
}

\author{
Tjang Daniel Chandra ${ }^{1 *}$, Abdur Rahman As'ari², I Nengah Parta ${ }^{3}$, Purwanto ${ }^{4}$, \\ Syaiful Hamzah Nasution ${ }^{5}$ \\ Universitas Negeri Malang $1,2,3,4,5$ \\ tjang.daniel.fmipa@um.ac.id¹ , abdur.rahman.fmipa@um.ac.id²,nengah.parta.fmipa@um.ac.id ${ }^{3}$, \\ purwanto.fmipa@um.ac.id ${ }^{4}$, syaiful.hamzah.fmipa@um.ac.id ${ }^{5}$
}

\begin{abstract}
Starting in 2021, the Ministry of Education and Culture will start implementing a national assessment. The national assessment measures two kinds of literacy, namely reading literacy and mathematical literacy (or numeracy). One of the main instruments used in the national assessment is the Minimum Competency Assessment (AKM) which measures students' reading literacy and mathematical literacy (numeracy). AKM numeracy is a new thing for junior high school mathematics teachers. Therefore, the UM mathematics department community service team plans to hold a numeration AKM preparation workshop for junior high school mathematics teachers in the city of Probolinggo. It is hoped that through this workshop, teachers can be prepared to make numerical AKM problems. It has been held 2 workshops. In the first workshop, the service team provided several materials such as an explanation of the numeracy $A K M$, the making of the numeration AKM problemss about geometry and algebra, and how to package the numeracy AKM questions in the form of an e-LKPD. Before the event ended, the teachers were asked to try to make AKM numeracy problems and e-LKPD. They were given 2 weeks to do the task and present the results at the second workshop. The results obtained from the workshop are that the teachers benefit from the AKM material and how to formulate numeric AKM problems.
\end{abstract}

Keywords: workshop; AKM problems .

\section{PENDAHULUAN}

Mulai tahun 2021 Kementerian Pendidikan dan Kebudayaan akan mulai menerapkan asesmen nasional. Berdasarkan buku Asesmen Nasional, Lembar Tanya Jawab (2020), asesmen nasional merupakan program penilaian terhadap mutu sekolah pada jenjang dasar dan menengah. Mutu satuan pendidikan dinilai berdasarkan hasil belajar murid yang mendasar ( literasi, numerasi, dan karakter ). Asesmen nasional perlu dilakukan untuk meningkatkan mutu pendidikan. Asesmen ini dirancang untuk menghasilkan informasi untuk memperbaiki kualitas belajar-mengajar yang akan meningkatkan hasil belajar murid.

Asesmen nasional mengukur dua macam literasi yaitu literasi membaca dan literasi matematika ( atau Numerasi ). Kedua materi ini dipilih karena merupakan kemampuan atau kompetensi mendasar dan diperlukan oleh semua murid. Literasi dan numerasi merupakan kompetensi yang perlu dikembangkan secara lintas mata pelajaran. Dengan mengukur literasi dan numerasi, Asesmen nasional mendorong guru semua mata pelajaran untuk berfokus pada pengembangan kompetensi membaca dan berpikir logis sistematis.

Salah satu instrumen utama yang digunakan dalam asesmen nasional adalah Asesmen Kompetensi Minimum (AKM) yang mengukur literasi membaca dan literasi matematika ( numerasi ) siswa. Konten yang diukur pada literasi membaca dan numerasi adalah konten yang bersifat esensial serta berkelanjutan lintas kelas maupun jenjang. Karena itu tidak semua konten pada kurikulum diujikan sehingga sifatnya minimum. Kemampuan membaca yang diukur melalui AKM Literasi dikembangkan tidak hanya melalui pelajaran Bahasa 
Indonesia tetapi juga melalui pelajaran agama, IPA, IPS, dan pelajaran lainnya. Demikian juga kemampuan berpikir logis sistematis yang diukur melalui AKM Numerasi juga sebaiknya dikembangkan melalui berbagai pelajaran.

Asesmen literasi membaca dan numerasi pada AKM dapat ditinjau dari 3 komponen yaitu konten, proses kognitif, serta konteks. Untuk literasi numerasi, konten meliputi aljabar, bilangan, geometri, pengukuran, data dan ketidakpastian. Proses kognitif meliputi pemahaman, penerapan, dan penalaran. Sedangkan konteks meliputi personal, sosial budaya, dan saintifik.

Berdasarkan pembahasan di atas, AKM numerasi merupakan hal yang baru bagi para guru matematika SMP. Demikian juga masih banyak guru-guru matematika SMP di kota Probolinggo yang belum mengikuti sosialisasi tentang AKM. Sehingga mereka belum mengetahui tentang materi AKM dan penyusunan soal AKM. Oleh karena itu tim pengabdian masyarakat jurusan matematika UM bekerja sama dengan MGMP Matematika SMP kota Probolinggo merencanakan mengadakan pendampingan bagi guru-guru matematika dalam penyusunan soal AKM numerasi. Tujuan pendampingan ini adalah menyiapkan para guru dalam pembuatan soal-soal AKM numerasi.

\section{METODE}

Sebelum kegiatan pengabdian kepada masyarakat dilaksanakan, tim mengadakan rapat beberapa kali untuk menentukan jadwal pelaksanaan dan metode yang akan digunakan yaitu berupa pendampingan. Tim juga mengadakan survey awal untuk mengetahui apakah para guru sudah mengetahui tentang AKM. Ada 28 guru yang menjawab survey awal. Sekitar 14 guru menyatakan bahwa mereka belum pernah mengikuti sosialisasi tentang AKM maupun tentang penyusunan soal AKM. Oleh karena itu kegiatan pendampingan ini tepat diterapkan untuk para guru.

Kegiatan workshop diadakan secara daring menggunakan fasilitas zoom pada hari Kamis 29 Juli 2021. Kegiatan ini diikuti oleh 40 orang guru matematika SMP sekota Probolinggo. Kegiatan pendampingan pertama ini dimulai dengan tim pengabdian memberikan beberapa materi seperti penjelasan tentang AKM numerasi oleh Prof. Dr. Asari. Dilanjutkan dengan penyampaian materi tentang pembuatan soal AKM numerasi tentang geometri dan aljabar oleh Prof. Dr. Purwanto dan Dr. I Nengah Parta.Yang terakhir bapak Syaiful Hamzah, M.Pd menyampaikan bagaimana mengemas soal AKM yang sudah dibuat dalam bentuk e-LKPD. Kegiatan berlansung mulai pukul $8-12$. Sebelum kegiatan diakhiri, para guru diminta untuk mencoba membuat soal AKM numerasi dan e-LKPD. Mereka diberi waktu 2 minggu untuk mengerjakan tugas tersebut dan mempresentasikan hasilnya pada workshop kedua.

Pendampingan kedua juga diadakan secara daring pada hari Kamis 19 Agustus 2021 dan dihadiri oleh 30 orang guru. Beberapa guru tidak hadir karena bersamaan dengan kegiatan lainnya di sekolah mereka. Tahapan pendampingan dimulai dengan mengingatkan materi pendampingan pertama oleh Dr. I Nengah Parta. Kemudian dilanjutkan dengan presentasi beberapa guru tentang soal AKM yang sudah dibuat. Berikutnya para nara sumber dan guru lainnya memberikan masukan untuk perbaikan soal. Setelah acara presentasi dan diskusi selesai para guru diberi waktu sekitar 1 jam untuk merevisi soal berdasarkan masukan-masukan yang sudah diperoleh. Acara dilanjutkan dengan penyajian soal-soal yang sudah direvisi. Acara pendampingan diakhiri dengan diskusi tentang e-LKPD 
yang sudah dibuat oleh guru. Tim pengabdian memberikan sertifikat kepada para guru yang mengikuti semua kegiatan pendampingan dan membuat soal AKM.

\section{HASILKARYA UTAMA DAN PEMBAHASAN}

Seperti dijelaskan di atas ada dua kegiatan pendampingan yang telah dilaksanakan. Pada kegiatan pertama para guru masih diberikan materi oleh para nara sumber dan diakhiri

dengan pemberian tugas yaitu menyusun soal AKM.Tugas ini akan didiskusikan di kegiatan pendampingan kedua.

Beberapa guru matematika pada sekolah yang sama membentuk kelompok dan mengumpulkan soal AKM numerasi dengan materi aljabar, bilangan, pengukuran dan geometri, data dan ketidakpastian. Beberapa soal dipresentasikan di pendampingan kedua dan mendapat masukan dari tim maupun dari guru lainnya. Setelah itu para guru memperbaiki dan mempresentasikan kembali hasil revisinya. Kegiatan pendampingan kedua menghasilkan soal-soal AKM yang dibuat para guru.

Berikut disajikan soal-soal yang dipresentasikan di kegiatan pendampingan kedua dan sudah direvisi berdasarkan masukan dari para nara sumber dan guru lainnya.

TUGAS PEMBUATAN SOAL AKM

1. Pada sebuah gedung pertunjukan ekslusif disusun kursi untuk barisan pertama sebanyak 6 , baris kedua 10 kursi, baris ketiga 14 kuri, baris keempat 18 kursi dan selanjutnya mengikuti pola yang sama . Banyak baris kursi dalam gedung tersebut pertunjukan adalah 10 baris. Karena kebijakan PPKM level 4, maka banyak penonton yang menduduki kursi hanya boleh diisi maksimal $50 \%$ dari kapasitas kursi yang ada. Berapa orang paling banyak dapat menempati kursi barisan paling belakang?

2. Pada sebuah gedung pertunjukan ekslusif disusun kursi untuk barisan pertama sebanyak 6 , baris kedua 10 kursi, baris ketiga 14 kuri, baris keempat 18 kursi dan selanjutnya mengikuti pola yang sama . Banyak baris kursi dalam gedung tersebut pertunjukan adalah 10 baris. Karena kebijakan PPKM level 4, maka banyak penonton yang menduduki kursi hanya boleh diisi maksimal $50 \%$ dari kapasitas kursi yang ada. Jika banyak penonton yang mengajukan pembelian tiket on line sebanyak 250 orang, maka berpa banyak penonton yang tidak mendapat tiket?

Gambar 1. Soal AKM tentang pola bilangan

Soal AKM di atas tentang barisan aritmetika sudah cukup bagus. Masukan yang diberikan ke penulis soal adalah sebaiknya diberikan tambahan gambar. Salah satu ciri soal AKM adalah ada ilustrasi gambar yang memperjelas maksud soal. (Susanto. dkk, 2021) 


\section{Tugas Pembuatan Soal Akm}

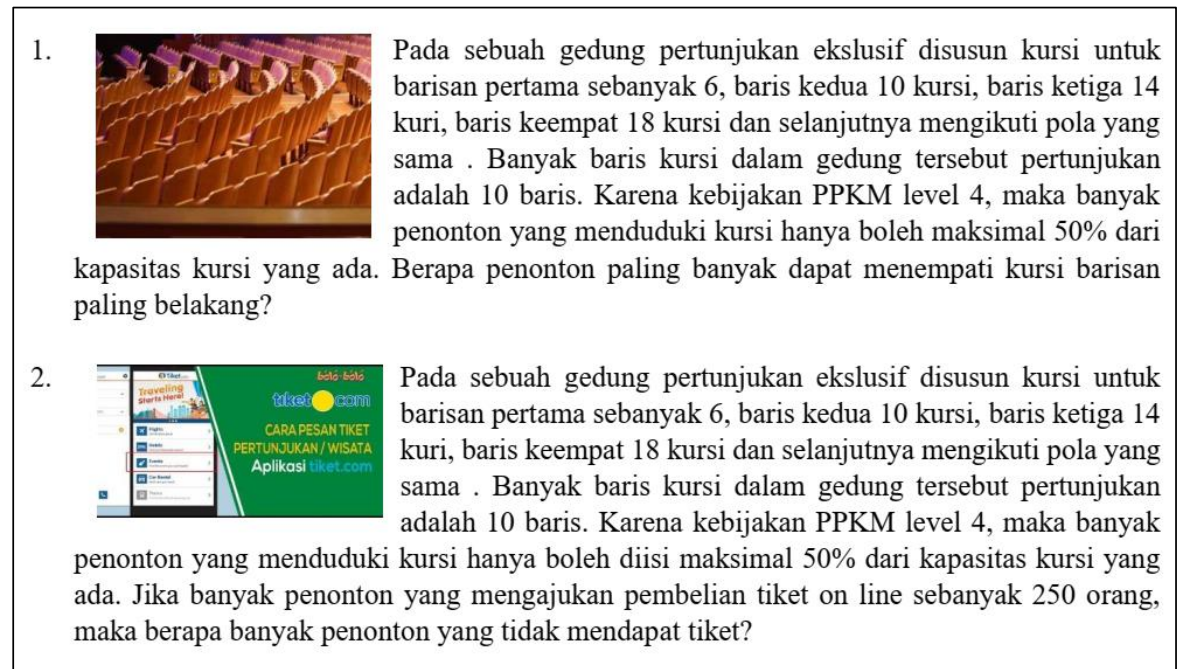

Gambar 2. Soal AKM yang sudah direvisi

Terlihat pada Gambar 2 soal AKM sudah dilengkapi dengan ilustrasi gambar. Masukan untuk soal AKM berikut bukan pada bagian soalnya tetapi perbaikan pertanyaannya.

\begin{tabular}{l}
\hline PERTANYAAN 1: \\
"Dari 38 Kab/kota di Jawa Timur, sebanyak 20 kab/kota termasuk zona merah dan 18 kab/kota termasuk \\
zona orange". \\
Benar ataukah Salah pernyataan tersebut? \\
B Benar \\
PERTANYAAN 2: \\
Terjadi kenaikan paling drastis kasus Covid-19 di Jawa Timur selama PPKM pada data tersebut adalah ..... \\
2.750 kasus \\
3.200 kasus \\
3.500 kasus \\
8.200 kasus \\
PERTANYAAN 3: \\
Berdasarkan tabel di atas, pernyataan yang paling benar adalah ..... \\
O Kasus positif covid-19 di Jawa Timur tidak stabil selama masa PPKM \\
Terjadi kenaikan kasus kematian di Jawa Timur yang cukup tinggi selama masa PPKM \\
Kasus positif covid-19 di Jawa Timur pernah mengalami kenaikan yang sangat tinggi pada \\
minggu ke-3 di masa PPKM. \\
Kasus covid-19 di Jawa Timur pada minggu ke-3 di masa PPKM cenderung mengalami \\
penurunan. \\
\hline
\end{tabular}

Gambar 3. Pertanyaan Soal AKM sebelum direvisi

Gambar berikut mnyajikan hasil setelah direvisi. Perintah yang ditambahkan diberikan warna biru. 
PEDULI: Jurnal Ilmiah Pengabdian Pada Masyarakat, 2021, Vol.5, No.2 ISSN: 25974653. EISSN:25974688

http://peduli.wisnuwardhana.ac.id/index.php/peduli/index

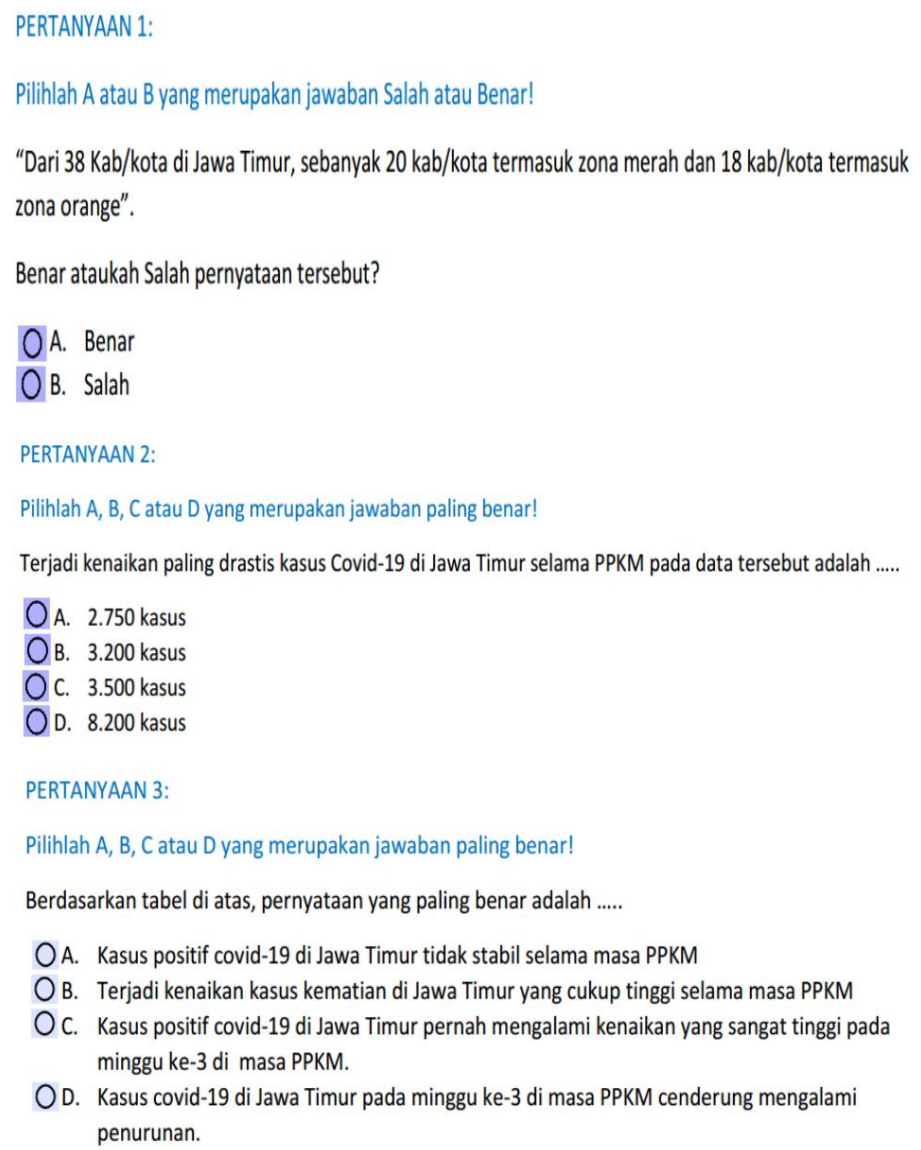

Gambar 4. Pertanyaan Soal AKM Setelah Direvisi

Penyusunan soal AKM harus memperhatikan tentang ketepatan konsep yang disajikan. Pada soal berikut tentang peluang, konsep yang ditampilkan kurang tepat. Soal menyajikan tentang diagram batang tentang banyaknya pelanggan toko yang membeli beras, minyak goreng, gula dan telor. Yang ditanyakan berapa peluang pelanggan yang membeli gula ? Untuk menyelesaikan soal peluang kita harus mengasumsikan bahwa masing-masing himpunan pelanggan yang membeli beras, himpunan pelanggan yang membeli minyak goreng, himpunan pelanggan yang membeli gula, dan himpunan pelanggan yang membeli telor tidak saling beririsan. Hal ini tidak logis karena biasanya pelanggan toko membeli beberapa item misalnya membeli telor dan minyak goreng. Karena itu soal AKM berikut perlu direvisi. Materi soal AKM berikut tentang data ketidakpastian ( peluang). 


\section{MATERI : DATA - KETIDAKPASTIAN}

\section{LEVEL 1 ( PENGETAHUAN)}

\section{SOAL}

Hasil survey pelanggan Toko Angkasa Raya selama PPKM pada tanggal 08/08/2021 dalam memenuhi kebutuhan pokok :

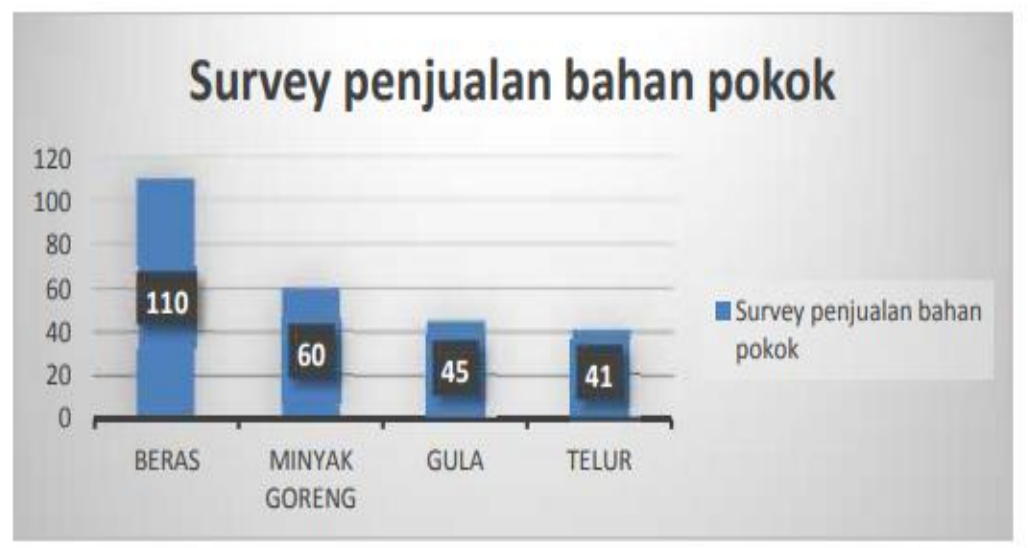

Banyak pelanggan pada hari tersebut sebanyak 256 orang. Jika seorang pelanggan dipilih secara acak, maka berapakah peluang pelanggan Gula ?

Gambar 5, Soal AKM Tentang Peluang

Guru merevisi soal sebagai berikut,

\section{MATERI : DATA - KETIDAKPASTIAN \\ ( REVISI ) \\ LEVEL 1 ( PENGETAHUAN )}

1. SOAL REVISI

Hasil survey penjualan BBM di salah satu SPBU di Kota X selama PPKM pada tanggal 19 Agustus 2021 di tunjukkan oleh grafik berikut

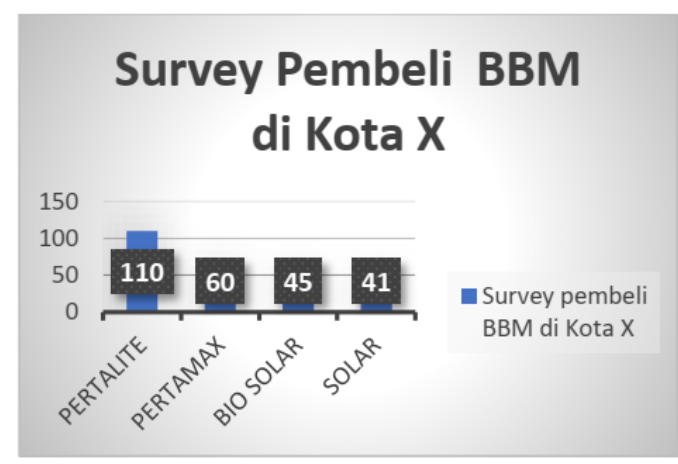

Gambar 6 Soal AKM Tentang Peluang setelah direvisi 
Banyak pembeli pada hari tersebut sebanyak 256 orang. Jika seorang pembeli dipilih secara acak, maka berapakah peluang pembeli Bio Solar?

Soal AKM setelah direvisi tampak lebih logis dan tepat dari segi konsep. Tidak mungkin pengendara kendaraan akan mengisi tangkinya dengan petralite dan petramax sekaligus.

Di akhir kegiatan pendampingan kedua, tim pengabdian menyebarkan angket kepada para guru untuk menampung pendapat mereka tentang kegiatan ini. Dari hasil angket diperoleh masukan bahwa para guru mendapatkan banyak manfaat seperti lebih memahami materi AKM numerasi, cara membuat soal AKM, dan bagaimana mengemas soal AKM dalam e-LKPD. Masukan dari para guru antara lain supaya kegiatan pendampingan ini dapat diadakan lagi secara luring dan disediakan waktu lebih banyak untuk berdiskusi tentang penyusunan soal AKM.

\section{.KESIMPULAN}

Berdasarkan kegiatan pendampingan yang sudah dilaksanakan didapatkan bahwa para guru mengerjakan tugas pembuatan soal AKM dengan baik. Meskipun beberapa soal AKM memiliki kelemahan tetapi para guru merevisi soal tersebut berdasarkan masukan yang diberikan nara sumber dan guru lainnya. Di samping itu para guru mengikuti semua kegiatan dari awal dengan baik dan antusias dalam membuat soal dan berdiskusi, meskipun saat kegiatan pendampingan kedua terjadi gangguan jaringan sehingga beberapa guru tidak maksimal dalam mempresentasikan soal AKM yang sudah dibuat. Hal ini membuat seluruh kegiatan pendampingan dapat berlangsung dengan baik.

\section{Ucapan Terima Kasih}

Tim Pengabdian kepada Masyarakat mengucapkan terima kasih kepada pengurus MGPM Matematika SMP Kota Probolinggo atas kerja samanya sehigga kegiatan workshop ini dapat berlangsung dengan baik. Juga kepada para guru Matematika SMP yang telah mengikuti semua kegiatan workshop dari awal hingga akhir dengan baik. .

\section{DAFTAR PUSTAKA}

Asesmen Nasional, Lembar Tanya Jawab, 2020. Pusat Asesmen dan Pembelajaran. Kementrian Pendidikan dan Kebudayaan.

AKM dan Implikasinya pada pembelajaran, 2020. Pusat Asesmen dan pembelajaran. Kementrian Pendidikan dan Kebudayaan.

Susanto, D. dkk., 2021, Inspirai Pembelajaran yang Menguatkan Numerasi buku 1, Jakarta : Kementerian Pendidikan, Kebudayaan, Riset, dan Teknoogi

Susanto, D. dkk., 2021, Inspirai Pembelajaran yang Menguatkan Numerasi buku 2, Jakarta : Kementerian Pendidikan, Kebudayaan, Riset, dan Teknoogi 